J. AMER. SOC Hort. SCI. 115(3):458-462. 1990.

\title{
Comparison of Extraction Methods for the Rapid Determination of Essential Oil Content and Composition of Basil
}

\author{
Denys J. Charles and James E. Simon \\ Department of Horticulture, Purdue University, West Lafayette, IN 47907 \\ Additional index words. solvent extraction, hydrodistillation, steam distillation, terpenes, Ocimum basilicum, Ocimum
kilimandscharicum, Ocimum micranthum
}

\begin{abstract}
Essential oils were extracted from leaves, flowers, and stems of Ocimum basilicurn, O. kilimandscharicum, and $O$. micranthum by solvent extraction, hydrodistillation, and steam distillation for essential oil content and the oil analyzed by GC and GC/MS for composition. While the yield of essential oil was consistently higher from steam distillation than hydrodistillation, a similar number of compounds was recovered from both hydrodistillation and steam distillation. Though the relative concentration of the major constituents was similar by both methods, the absolute amounts were higher with steam distillation. Essential oil content and composition varied by plant species and plant part. Essential oil content was highest in flowers for O. basilicum and in leaves for O. micranthum. No significant differences were observed in essential oil yield and relative concentration of major constituents using fresh or dry samples and using samples from $75 \mathrm{~g}$ to $10 \mathrm{~g}$ of dry plant tissue. While minor differences between hydrodistillation and steam distillation were observed, both methods resulted in high yields and good recovery of essential oil constituents. Hydrodistillation is a more-rapid and simpler technique than steam and permits the extraction of essential oil where steam is not accessible.
\end{abstract}

Essential oils are a diverse group of natural products that are important sources of aromatic and flavoring chemicals in food, industrial, and pharmaceutical products. Essential oils are largely composed of terpenes and aromatic polypropanoid compounds derived from the acetate-mevalonic acid and the shikimic acid pathways, respectively. Essential oil composition of plants varies and is due to genetic and environmental factors that influence genetic expression (Bernath, 1986). The essential oil content of plant tissue also varies with developmental stage (Burbott and Loomis, 1967), and can vary by extraction methods (Guenther, 1972).

Techniques commonly employed for extracting essential oils include hydrodistillation (ASTA, 1968), steam distillation (Chialva et al., 1982), solvent extraction (Burbott and Loomis, 1967), head space analysis (Chialva et al., 1982), and liquid $\mathrm{CO}_{2}$ extraction (Takeoka et al., 1985). The composition of the extracted oil may vary from one extraction method to another. Head space analysis offers a potentially rapid method to extract essential oils and requires very little plant material, but complete recovery occurs only for highly volatile materials (Takeoka et al., 1985). Steam distillation and solvent extraction as conventionally applied result in severe losses of volatile materials because the liquid in which the oil is collected must be subsequently removed by evaporation (Burbott and Loomis, 1967; Chialva et al., 1982). Solvent extraction results in the recovery of nonvolatile compounds (Burbott and Loomis, 1967). While liquid $\mathrm{CO}_{2}$ extraction can give reliable and efficient recovery with little or no decompositional changes induced by the extraction process, this process is expensive and used limitedly in commerce. Moreover, similar results can be obtained by hydro- or steam distillation (Kasting et al., 1972, Takeoka et al., 1985).

Rapid techniques for extracting essential oils from relatively small amounts of plant tissue would be useful to characterize

\footnotetext{
Received for publication 20 May 1988. Journal Paper no. 11,704, Purdue Univ. Agr. Expt. Sta., West Lafayette, IN 47907. This research was supported by a grant from the Purdue Univ. Agr. Expt. Sta. (Specialty Crops Grant no. 0141165-0000-65178). The cost publishing this paper was defrayed in part by the payment of page charges. Under postal regulations, this paper therefore must be hereby marked advertisement solely to indicate this fact.
}

essential oils in aromatic plants. Important contributions have already been made towards solving this problem. Godefroot et al. (1981) described a modified Likens and Nickerson apparatus (1964) in which the volatiles are collected in only $1 \mathrm{ml}$ of solvent during continuous steam distillation and extraction. One to $15 \mathrm{~g}$ of plant material, the amount depending on the content of essential oil, are required, and a complete analysis, including gas chromatographic separation, can be performed in less than $4 \mathrm{hr}$. Another micro-scale apparatus for steam distillation has been developed by Bicchi et al. (1983) in which very small amounts of plant material $(1 \mathrm{~g})$ are required. The complete analysis takes about $2 \mathrm{hr}$. However, the apparatus used in these methods are expensive, limiting their usefulness for large numbers of samples. Inferences on the yield of essential oil from such small amounts of plant tissue (one to two leaves) to the entire plant or plant populations are also limited.

In this paper, we compare the influences of three extraction methods-on measurements of essential oil content and composition in various plant parts of Ocimum spp. with the objective of developing a simple, rapid, and reliable extraction technique for this species in which the yield of essential oil can be accurately determined.

\section{Materials and Methods}

\section{Plant material}

Ocimum basilicum L. (Harris-Moran Seed Co., Rochester, N.Y.), O. kilimandscharicum (USDA Midwestern Regional Plant Introduction Centers, Ames, Iowa), and O. micranthum Willd. (Companion Plants, Athens, Ohio) were field-grown at the Purdue Univ. Vegetable Research Farm (Lafayette, Ind.) during Summer 1987 and harvested while in full bloom in October. All above-ground portions were harvested and weighed, and the leaves, flowers, and stems were separated. Essential oils were then extracted from known weights (75 g dry weight or $200 \mathrm{~g}$ fresh weight) of leaves, flowers, 'stems, or an equal mixture of leaves and flowers. The samples were oven-dried at $30 \mathrm{C}$ for 3 days to 1 week. In experiments where different sample amounts 
Table 1. Yield of essential oil from Ocimum basilicum, O. micranthum, and O. kilimandscharicum.

\begin{tabular}{|c|c|c|c|c|c|c|c|}
\hline \multirow[b]{2}{*}{$\begin{array}{l}\text { Extraction } \\
\text { method }\end{array}$} & \multicolumn{3}{|c|}{ O. basilicum } & \multicolumn{3}{|c|}{ O. micranthum } & $\begin{array}{l}\text { O. kilimand } \\
\text { scharicum }\end{array}$ \\
\hline & Leaves & Flowers & $\begin{array}{l}\text { Leaves and } \\
\text { Hlowers. }\end{array}$ & Leaves & Flowers & $\begin{array}{l}\text { Leaves and } \\
\text { flowers }\end{array}$ & $\begin{array}{c}\text { Leaves and } \\
\text { flowers }\end{array}$ \\
\hline \multicolumn{8}{|c|}{$(\%$ Yield $m l / 100 \mathrm{~g} d r y w t \pm s D)$} \\
\hline $\begin{array}{l}\text { Hydrodistillation } \\
\text { Steam distillation }\end{array}$ & $\begin{array}{l}0.95 \pm 0.08 \\
1.31 \pm 0.04\end{array}$ & $\begin{array}{l}2.00 \pm 0.08 \\
2.11 \pm 0.05\end{array}$ & $\begin{array}{l}1.25 \pm 0.05 \\
1.65 \pm 0.05\end{array}$ & $\begin{array}{l}1.54 \pm 0.12 \\
1.89 \pm 0.06\end{array}$ & $\begin{array}{l}0.63 \pm 0.08 \\
0.91 \pm 0.04\end{array}$ & $\begin{array}{l}1.40 \pm 0.05 \\
1.53 \pm 0.06\end{array}$ & $\begin{array}{l}1.93 \pm 0.15 \\
2.36 \pm 0.08\end{array}$ \\
\hline \multicolumn{8}{|c|}{$D r y w t\left(\mu l \cdot g^{-1} \pm S D\right)$} \\
\hline $\begin{array}{l}\text { Hydrodistillation } \\
\text { Steam distillation }\end{array}$ & $\begin{array}{r}9.5 \pm 0.80 \\
13.1 \pm 0.40\end{array}$ & $\begin{array}{l}20.0 \pm 0.80 \\
21.1 \pm 0.50\end{array}$ & $\begin{array}{l}12.5 \pm 0.50 \\
16.5 \pm 0.50\end{array}$ & $\begin{array}{l}15.4 \pm 1.20 \\
18.9 \pm 0.60\end{array}$ & $\begin{array}{l}6.3 \pm 0.80 \\
9.1 \pm 0.40\end{array}$ & $\begin{array}{l}14.0 \pm 0.50 \\
15.3 \pm 0.60\end{array}$ & $\begin{array}{l}19.3 \pm 1.50 \\
23.6 \pm 0.80\end{array}$ \\
\hline
\end{tabular}

Table 2. Essential oil composition from leaves of Ocimum basilicurn as affected by three extraction methods.

\begin{tabular}{|c|c|c|c|c|c|c|c|}
\hline \multirow{2}{*}{$\begin{array}{l}\text { Essential oil } \\
\text { constituents }\end{array}$} & \multicolumn{5}{|c|}{$\begin{array}{l}\text { Essential oil composition } \\
\text { (\% total essential oil } \pm \text { SD) }\end{array}$} & \multicolumn{2}{|c|}{$\begin{array}{l}\text { Essential oil content } \\
\left(\mu \mathrm{l} \cdot \mathrm{g}^{-1} \text { dry wi }\right)\end{array}$} \\
\hline & RT & HD & $\mathrm{SD}$ & OS & & $\mathrm{HD}$ & $\mathrm{SD}$ \\
\hline$\alpha$-pinene & 4.7 & $0.09 \pm 0.0$ & $0 . \overline{0.08} \pm 0.0$ & $0.04 \pm$ & 0.0 & 0.009 & 0.01 \\
\hline B-pinene & 5.9 & $0.32 \pm 0.1$ & $0.32 \pm 0.1$ & $0.16 \pm$ & 0.1 & 0.03 & 0.04 \\
\hline 1,8-cineole + limonene & 7.5 & $7.37 \pm 1.2$ & $8.87 \pm 1.5$ & $1.65 \pm$ & 0.8 & 0.70 & 1.16 \\
\hline Trans B-ocimene & 7.8 & $0.15 \pm 0.0$ & $0.30 \pm 0.0$ & $0.07 \pm$ & 0.0 & 0.01 & 0.04 \\
\hline$\gamma$-terpinene & , 8.3 & $0.06 \pm 0.0$ & $0.09 \pm 0.0$ & $0.01 \pm$ & 0.0 & 0.003 & 0.01 \\
\hline Linalool & 10.4 & $48.2 \pm 9.5$ & $48.1 \pm 8.9$ & $62.8 \pm$ & 10.3 & 4.58 & 6.30 \\
\hline Camphor & 11.9 & $0.15 \pm 0.1$ & $0.44 \pm 0.2$ & $0.10 \pm$ & 0.0 & 0.02 & 0.05 \\
\hline Menthol : & 13.2 & $0.34 \pm 0.1$ & $0.87 \pm 0.2$ & $0.21 \pm$ & 0.0 & 0.03 & 0.11 \\
\hline Methyl chavicol & 14.2 & $31.6 \pm 6.1$ & $28.3 \pm 6.0$ & $16.2 \pm$ & 5.2 & 3.00 & 3.71 \\
\hline Geraniol & 17.7 & $0.10 \pm 0.0$ & $0.20 \pm 0.1$ & $0.04 \pm$ & 0.0 & 0.01 & 0.03 \\
\hline Eugenol & 21.0 & $0.13 \pm 0.0$ & $0.62 \pm 0.3$ & $0.51 \pm$ & 0.5 & 0.01 & 0.10 \\
\hline B-caryophyllene & 24.1 & $1.67 \pm 0.9$ & $0.79 \pm 0.9$ & $1.64 \pm$ & 0.8 & 0.16 & 0.02 \\
\hline Cinnamyl acetate & 25.1 & $0.15 \pm 0.1$ & $0.16 \pm 0.1$ & $0.11 \pm$ & 0.0 & 0.02 & 0.06 \\
\hline a-humulene & 26.9 & $0.39 \pm 0.1$ & $0.42 \pm 0.2$ & $0.26 \pm$ & 0.1 & 0.04 & 0.06 \\
\hline Elemene & 30.4 & $0.06 \pm 0.0$ & $0.07 \pm 0.0$ & $0.35 \pm$ & 0.1 & 0.01 & 0.01 \\
\hline
\end{tabular}

${ }^{\mathrm{z} T}=$ retention time; $\mathrm{HD}=$ hydrodistillation; $\mathrm{SD}=$ steam distillation; $\mathrm{OS}=$ organic solvent extraction.

were used, the dry weights of the samples were $75,20,15$, and $10 \mathrm{~g}$.

\section{Essential oil extraction}

Essential oil was extracted from each of the plant parts by three extraction methods:

Hydrodistillation. Plant material was placed in a 2-liter roundbottomed flask with distilled, deionized water $(1000 \mathrm{ml}$ for 75 $\mathrm{g}$ dry material and $400 \mathrm{ml}$ for $200 \mathrm{~g}$ fresh material) and the essential oil was extracted by water distillation using a modified clevenger trap (ASTA, 1968). For smaller plant -samples, the amount of water was adjusted proportionally ( $1 \mathrm{~g}$ dry material : $13.3 \mathrm{ml}$ water). The distillation period was $1 \mathrm{hr}$ (fresh samples) and $1 \mathrm{hr} 15 \mathrm{~min}$ (dried samples), and the essential oil content was determined on an oil volume to tissue weight (fresh/dry) basis.

Steam distillation. Steam distillation was carried out by passing steam into a 3-liter round-bottomed flask containing the dried or fresh plant material for $90 \mathrm{~min}$ and collecting the condensate (water and oil) in a round-bottomed flask. The condensate was extracted three times with ethyl ether to completely extract the essential oil. Sodium Sulfate was added to the ethyl ether to remove moisture. Ethyl ether was then removed by rotary evaporation and the essential oil content determined on a volume to tissue weight (fresh/dry) basis.

Solvent extraction. Solvent extraction of essential oil was carried out by the method of Burbott and Loomis (1967). Plant material was ground in a mortar containing hexane and anhydrous $\mathrm{Na}_{2} \mathrm{SO}_{4}$ and extracted four times with hexane to give a total volume of $10 \mathrm{ml}$ of yellow extract. A small amount of Norit A charcoal, just sufficient to remove the yellow pigment, was added to each extract and then removed by centrifugation at low speed. The clear solutions were then concentrated under a stream of air at room temperature.

Essential oil samples were stored in silica vials with teflonsealed caps at $2 \mathrm{C}$ in the dark. The essential oil contents reported are means of triplicate extractions.

\section{Essential oil identification and quantification}

Essential oil samples from each of the extractions were analyzed by gas chromatography (CC) using a Varian 3700 gas chromatograph equipped with FID and a Varian electronic 4270 integrator (Varian, Walnut Creek, Calif.). A fused silica capillary column $(12 \mathrm{~m} \times 0.22 \mathrm{~mm}$ i.d.) with an OV 101 (Varian, polydimethylsiloxane) bonded phase was used to separate the oil constituents. Direct injection of $0.5 \mu \mathrm{l}$ of essential oil samples with helium as a carrier gas (100:1 split-vent ratio) and oven temperature held isothermal at $80 \mathrm{C}$ for $2 \mathrm{~min}$ and then programmed to increase at $3 \mathrm{C} / \mathrm{min}$ to $180 \mathrm{C}$ gave complete elution of all peaks (sensitivity $10^{-10}$ ). The injector and detector temperatures were 180 and 300C, respectively. Essential oil constituents were identified based on retention time and by coinjection with authentic compounds, and the relative peak area for individual constituents was determined for each plant part. 


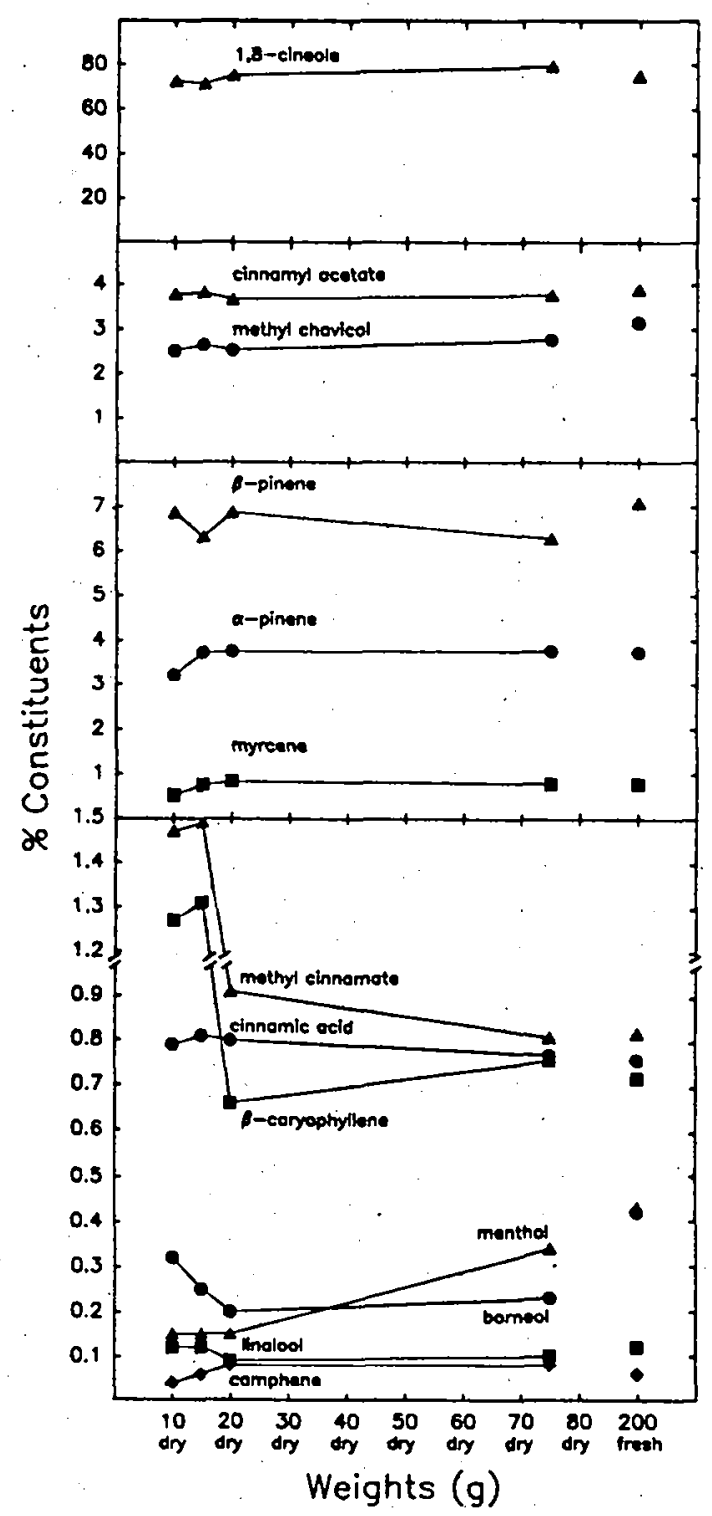

Fig. 1. Relative percentage of selected essential oil constituents from leaves and flowers of $O$. kilimanadscharicum as influenced by quantity of plant tissue used in the hydrodistillation.

\section{GC/mass spectroscopy analysis}

Pure compounds and essential oil constituents were verified by GC/MS. A Finnigan (San Jose, Calif.) GC (9610) and MS (4000) hooked on-line to a Data General Nova/4 data processing system, used electron impact analysis. The GC conditions were: direct injection of 1.0- $\mu \mathrm{l}$ sample diluted 10:1 with $\mathrm{MeOH}$; fused silica column $(30 \mathrm{~m} \times 0.25 \mathrm{~mm})$ with DB-1 bonded phase (polydimethylsiloxane) (J\&W Scientific, Folsom, Calif.); helium as a carrier gas with a column pressure of $72.2 \mathrm{kPa}(10.5 \mathrm{psi})$ and split vent of $40 \mathrm{ml} \cdot \mathrm{min}^{-1}$; oven program of $80 \mathrm{C}$ for $2 \mathrm{~min}$, rising to $180 \mathrm{C}$ at $2 \mathrm{C}$ per min; and injector temperature of $225 \mathrm{C}$.

The MS conditions were: ionization voltage of $70 \mathrm{eV}$; emission current of $40 \mu \mathrm{A}$; scan rate and range of one scan per second and 40 to 500, respectively; and a source temperature of $160 \mathrm{C}$.

\section{Results and Discussion}

In order to develop an efficient and simple method of essential oil extraction, we evaluated hydrodistillation, steam distillation and organic solvent extraction using three basil species and different plant parts. The yield of essential oil from leaves, flowers, and stems of $O$. basilicum and $O$. micranthum and leaves and flowers from $O$. kilimandscharicum as extracted by steam and hydrodistillation is shown in Table 1. Preliminary studies indicated that organic solvent extraction of essential oil for yield was difficult because essential oil losses occurred during solvent evaporation, and incomplete evaporation of the solvent could inflate the essential oil yield (data not shown). Thus, where total yield of essential oil is the primary objective, organic solvent extraction can be problematic. Recovery of essential oil was significantly higher with steam distillation, in agreement with the results reported by other workers (Guenther, 1972; Heath, 1981).

No significant differences were observed in the concentration of the 15 constituents identified in the essential oils obtained by steam distillation and hydrodistillation (Table 2). Organic solvent extraction resulted in oil with fewer constituents than hydro- or steam distillation, and the relative percentage of major constituents was different from that obtained by hydro- or steam distillation (Table 2). Similar results were found with O. micranthum and $O$. kilimandscharicum (data not shown). By hydro- and steam distillation, 32 to 35 constituents were obtained, while with organic solvent only 22 compounds were observed (data not shown). Of the three methods of extraction evaluated, hydrodistillation consistently resulted in an oil with the greatest number of constituents. The highly volatile constituents were present only in the organic solvent extract (only the major identified constituents are reported here).

There were four major constituents in $O$. basilicum oil: linalool, methyl chavicol, 1,8-cineole + limonene and $\beta$-caryophyllene (Table 2). This type of oil is representative of French or European basil oil (Simon et al., 1984). The concentration of 1,8-cineole + limonene was significantly higher in oils obtained by hydro- $(7.37 \%)$ and steam $(8.87 \%)$ distillation methods than in the oils obtained by organic solvent extraction (1.65\%). Linalool, the major constituent, was $48.2 \%$ and $48.1 \%$ in oils obtained by hydro- and steam distillation, respectively, but $62.8 \%$ by organic solvent extraction. Similarly, methyl chavicol was $31.6 \%$ and $28.3 \%$ by hydro- and steam distillation, respectively, but only $16.2 \%$ by organic solvent extraction.

Kasting et al. (1972) have reported that a concentrate obtained by isopentane extraction contained almost the same constituents as that extracted by steam distillation. However, their quantitative comparison indicated that recovery of several compounds was higher from steam distillation, while that of other compounds was higher from the isopentane extraction method. This result is in agreement with ours. Kasting et al. (1972) also observed that some compounds with low boiling points, which were identified in headspace vapors, were not detected in steam distillation, presumably due to volatilization during processing. Takeoka et al. (1985) found that the chromatogram of head space vapors was dominated by the more volatile components, and many of the higher boiling compounds were totally absent. In our experiments (data not shown) with all three Ocimum spp., similar results were obtained. Although we originally speculated that some of the observed peaks in the chromatogram following hydrodistillation could be due to the breakdown of naturally occurring compounds, on a relative percentage, the essential oil constituents obtained by hydrodistillation and steam distillation were very similar. For studies of the volatile chemical components in basil, we favor hydrodistillation over steam distillation or organic solvent extraction, because the former gave a high 
Table 3. Essential oil composition of Ocimum basilicum as affected by plant parts.

\begin{tabular}{|c|c|c|c|c|c|c|}
\hline \multirow{2}{*}{$\begin{array}{l}\text { Essential oil } \\
\text { constituents }\end{array}$} & \multicolumn{6}{|c|}{ Hydrodistillation } \\
\hline & Leaves & Flowers & Stems & Leaves & Flowers & Stems \\
\hline . & \multicolumn{3}{|c|}{$(\%$ cotal essential oil $\pm S D)$} & \multicolumn{3}{|c|}{$\left(\mu l \cdot g^{-1} d r y w t\right)$} \\
\hline$\alpha$-pinene & $0.09 \pm 0.0^{2}$ & $0.01 \pm 0.0$ & $0.1 \pm 0.0$ & 0.009 & 0.002 & 0.0002 \\
\hline B-pinene & $0.32 \pm 0.1$ & $0.04 \pm 0.0$ & $0.8 \pm 0.1$ & 0.03 & 0.008 & 0.0012 \\
\hline 1,8-cineole + limonene & $7.37 \pm 1.2$ & $2.53 \pm 0.7$ & $1.5 \pm 0.1$ & 0.70 & 0.506 & 0.0023 \\
\hline Trans $\beta$-ocimene & $0.15 \pm 0.0$ & $0.09 \pm 0.0$ & $0.08 \pm 0.0$ & 0.01 & 0.018 & 0.0001 \\
\hline$\gamma$-terpinene & $0.06 \pm 0.0$ & $0.07 \pm 0.0$ & $0.02 \pm 0.0$ & 0.003 & 0.014 & 0.0001 \\
\hline Linalool & $48.2 \pm 9.5$ & $73.9 \pm 4.8$ & $30.4 \pm 1.4$ & 4.58 & 14.8 & 0.05 \\
\hline Camphor & $0.15 \pm 0.1$ & $0.21 \pm 0.2$ & $0.04 \pm 0.0$ & 0.02 & 0.042 & 0.0001 \\
\hline Menthol & $0.34 \pm 0.1$ & $0.46 \pm 0.2$ & $0.08 \pm 0.0$ & 0.03 & 0.092 & 0.0012 \\
\hline Methyl chavicol & $31.6 \pm 6.1$ & $11.5 \pm 4.0$ & $12.6 \pm 1.0$ & 3.00 & 2.304 & 0.02 \\
\hline Geraniol & $0.10 \pm 0.0$ & $0.11 \pm 0.1$ & $1.6 \pm 0.2$ & 0.01 & 0.022 & 0.0024 \\
\hline Eugenol & $0.13 \pm 0.0$ & -- & $\ldots$ & $\cdots$ & $\cdots$ & 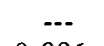 \\
\hline$\beta$-caryophyllene & $1.67 \pm 0.9$ & $0.64 \pm 0.2$ & $4.0 \pm 0.9$ & 0.01 & 0.128 & 0.006 \\
\hline Cinnamyl acetate & $0.15 \pm 0.1$ & $0.12 \pm 0.1$ & $0.4 \pm 0.1$ & 0.16 & 0.024 & 0.0006 \\
\hline$\alpha$-humulene & $0.39 \pm 0.1$ & $0.23 \pm 0.1$ & $0.9 \pm 0.2$ & 0.02 & 0.046 & 0.0014 \\
\hline Elemene & $0.06 \pm 0.0$ & $0.04 \pm 0.0$ & $0.2 \pm 0.0$ & 0.04 & 0.008 & 0.0003 \\
\hline
\end{tabular}

${ }^{\mathrm{z}}$ The values presented are means \pm SD of relative percentage.

yield of oil, good recovery of essential oil constituents, and was simpler and faster than the latter methods.

While research techniques have been developed that require only a single leaf, yield estimates are problematic with such small sample sizes. Thus, while ASTA (1968) recommends the use of $75 \mathrm{~g}$ dry or $200 \mathrm{~g}$ fresh weight for quantification of essential oil contents, the use of reduced amounts of plant material is highly desirable as long as similar information about yield and composition can be made. Different sample amounts of dried leaves of $O$. kilimandscharicum $(10,15,20$, or $75 \mathrm{~g}$ dry weight and $200 \mathrm{~g}$ fresh weight) were used to extract essential oils by hydrodistillation to determine if sample size could influence the efficiency of oil extraction and oil composition (Fig. 1). In all cases, yield of essential oil was about the same $(1.5 \%$ to $1.7 \%$ ), the number of peaks was identical, and there was little change in the concentration of individual essential oil constituents. Similar results were obtained with $O$. micranthum (data not shown). Thus, smaller amounts of plant material for basil can be used in the hydrodistillation of essential oils while maintaining the ability to extrapolate yield information from the reduced sample sizes. The ability to harvest smaller quantities of plant material should be of value to those in horticultural research where plant material is limited.

Using hydrodistillation, the content of essential oil from $O$. basilicum was higher in flowers (67\%) than in leaves $(32 \%)$, but in $O$. micranthum, the reverse was obtained (28\% in flowers and $68 \%$ in leaves). The concentration of essential oil glands in plant parts is highly species-dependent (Croteau, 1985). Werker et al. (1985) reported that the content of oil was always higher in flowers than leaves in four chemotypes of Origanum vulgare. In both $O$. basilicum and $O$. micranthum there were significant differences in the concentration of constituents among the different plant parts. In $O$. basilicum, linalool, the major constituent, was highest $(73.9 \%)$ in flowers, and only $48.2 \%$ and $30.4 \%$ in leaves and stems; respectively. Methyl chavicol was highest in leaves $(31.6 \%)$ with only $11.5 \%$ and $12.6 \%$ in flowers and stems, respectively (Table 3 ). The oil obtained from stems was higher in sesquiterpenes ( $\beta$-caryophyllene, cinnamyl acetate, $\alpha-$ humulene and elemene) than that from the other structures.

Drying of samples has been known to alter the composition of their essential oils (Greenhalgh, 1982; Lawrence et al., 1972).
Fresh leaves and flowers and dry leaves and flowers of $O$. $m i$ cranthum were extracted by hydrodistillation to observe the influence of low temperature forced-air drying (25 to 30C), in the absence of light, on oil content and composition. Though the content of oil obtained from dry tissue was higher than from fresh tissue due to the lower water content, no significant differences were observed in the concentration of the constituents (data not shown). This finding is of significance in research where many samples need to be analyzed or when plant material cannot be immediately distilled. Commercially, essential oil crops, such as peppermint and spearmint, are partially field-dried or cured after harvest prior to distillation. Thus, when basil is dried at low temperatures (25 to 30C), stored properly, and freshly ground before oil extraction to conserve as many of the volatile principles as possible, the oil composition will be similar to extraction from fresh plant material. However, the storage period of dried basil for conservation of essential oil warrants further study.

Hydrodistillation appears to be an excellent method for extracting the essential oil of basil as it results in good yield, good recovery of essential oil constituents, is less labor-intensive, and is simpler and faster than steam distillation. The ability to use either fresh or dry plant tissue, or to reduce the amount of dried plant material from 75 to $10 \mathrm{~g}$ dry weight with no significant changes in content and composition offers great promise in physiological and breeding studies where many samples must be analyzed and the amount of plant material may be limited. The advantage of solvent extraction is in single-leaf analysis when plant material is very limited or where the major essential oil constituents, rather than essential oil content, is of primary interest.

\section{Literature Cited}

ASTA. 1968. Official analytical methods of the American Spice Trade Association. ASTA, Englewood Cliffs, N.J. p. 8-11.

Bernath, J. 1986. Production ecology of secondary plant products, p. 185-234. In: L.E. Craker and J.E. Simon (eds.). Herbs, spices and medicinal plants: Recent advances in botany, horticulture, and pharmacology. vol. 1. Oryx Press, Phoenix, Ariz.

Bicchi, A., D.G.M. Nano, and C. Frattini. 1983. Improved method for the analysis of small amounts of essential oils by microdistillation followed by capillary gas chromatography. J. Chrom. 279:409-416. 
Burbott, A.J. and W.D. Loomis. 1967. Effects of light and temperature on the monoterpenes of peppermint. Plant Physiol. 42:20-28.

Chialva, F., G. Gabri, P.A.P. Liddle, and F. Ulian. 1982. Qualitative evaluation of aromatic herbs by direct head space $(\mathrm{GC})^{2}$ analysis. Applications of the method and comparison with the traditional analysis of essential oils, p. 183-195. In: N. Margaris, A. Koedam, and D. Vokou (eds.). Aromatic plants-basic and applied aspect. Martinus Nijhoff, Netherlands.

Croteau, R. 1986. Biochemistry of monoterpenes and sesquiterpenes of the essential oils, p. 81-133. In: L.E. Craker and J.E. Simon (eds.). Herbs, spices, and medicinal plants: Recent advances in botany, horticulture, and pharmacology, vol. 1. Oryx Press, Phoenix, Ariz.

Godefroot, M., P. Sandra, and M. Verzele. 1981. New method for quantitative essential oil analysis. J. Chrom. 203:325-335.

Greenhalgh, P. 1982. Production, trade and markets for culinary herbs. p. 139-166. In: C.K. Atal and B.M. Kapoor (eds.). Cultivation and utilization of aromatic plants. Regional research laboratory, JammuTawi, India.

Guenther, E. 1972. The production of essential oils, p. 87: In: E. Guenther (ed.). The essential oils. Krieger Publ. Co., Malabar, Fla.
Heath, H.B. 1981. Source book of flavors. AVI, Westport, Conn.

Kasting, R., J. Anderson, and E. van Sydow. 1972. Volatile constituents in leaves of parsley. Phytochemistry 11:2277-2282.

Lawrence, B.M., J.W. Hogg, S.J. Terhune, and N. Pichitakul. 1972. Essential oils and their constituents. IX. The oils of Ocimum sanctum and Ocimum basilicum from Thailand. Flavor Ind. Jan. p. 47-49. Lickens, S. and G. Nickerson. 1964. New method for essential oil analysis. Proc. Amer. Soc. Brew. Chem. p. 5-10.

Simon, J.E., A.F. Chadwick, and L.E. Craker. 1984. Basil. Herbs: An indexed bibliography, 1971-1980. The scientific literature on selected herbs, and aromatic and medicinal plants of the temperate zone. Archon Books, Hamden, Conn. p. 7-9.

Takeoka, G., S. Ebeler, and W. Jennings. 1985. Capillary gas chromatographic analysis of volatile flavor compounds, p. 96-108. American Chemical Society Symp. Ser. 289, Amer. Chem. Soc., Washington, D.C.

Werker, E., E. Putievsky, and U. Ravid. 1985. The essential oils and glandular hairs in different chemotypes of Origanun vulgare L. Ann. Bot. 55:793-801.

J. AMER. SOC. HORT. SCI. 115(3):462-467. 1990.

\title{
Seasonal Changes of Membrane Lipids in Apple Shoots
}

\author{
Shiow Y. Wang and Miklos Faust \\ Fruit Laboratory, Beltsville Agricultural Research Center, Agricultural Research Service, U.S. \\ Dept. of Agriculture, Beltsville, MD 20705 \\ Additional index words. Malus domestica, fatty acids, glycolipid, phospholipid, sterols
}

\begin{abstract}
Composition changes in galactolipids, phospholipids, and sterols in apple shoots (Malus domestica Borkh. cv. Red Delicious) from August to April were determined. The predominant fatty acids in the membrane lipids of apple shoots were palmitic acid (C16:0), linoleic acid (C18:2), and linolenic acid (C18:3). The major galactolipid components in apple shoots were monogalactosyl diglyceride (MGDG) and digalactosyl diglyceride (DGDG). The amount of MGDG and DGDG increased from autumn to spring. Galactolipids contained highly unsaturated fatty adds, mainly linoleic (18:2) and linolenic (18:3) acid. The major individual phospholipids were phosphatidylcholine (PC) and phosphatidylethaeolamine (PE). $\beta$-Sitosterol and sitosteryl ester were the predominant sterols. The phloem contained higher amounts of galactolipids, phospholipids, and sterols than did the xylem tissue. There was a significant increase in the content of galactolipids and phospholipids and onsaturation of their fatty acids during cold acclimation. A decrease in the ratio of free sterols to phospholipids also occurred in apple shoots toward cold winter months. Composition changes in galactolipids, phospholipids, and sterols that were associated with growth cessation, defoliation and cold acclimation from fall to winter, were mostly reversed foilowing deacclimation in spring.
\end{abstract}

Growth temperature has a major influence on membrane fatty acid composition and unsaturation. Changes in composition of the fatty acid components of membrane lipids are important in the acclimation of most types of plants (Martin et al., 1976). Most deciduous fruit trees growing in temperate climates develop some degree of cold hardiness with the onset of winter. Many plants capable of cold hardening exhibit an increase in lipid unsaturation (Willemot, 1975) and an increase in the level of phospholipids during hardening (de la Roche, 1979; Sikorska and Kacperska-Palacz, 1979; Siminovitch et al., 1968; Willemot, 1975). This change is probably one of several factors in maintaining membrane permeability and in regulating the activ-

\footnotetext{
Received for publication 9 Jan. 1989. We thank Amy L. Jordan for technical assistance. Use of a company or product name does not constitute an endorsement by USDA nor imply approval to the exclusion of other suitable products. The cost of publishing this paper was defrayed in part by the payment of page charges. Under postal regulations, this paper therefore must be hereby marked advertisement solely to indicate this fact.
}

ity of membrane-associated enzymes (Cronan and Gelmann, 1975; Raison, 1985).

Sterols play a vital role during the growth and development of higher plants (Garg and Paleg, 1986). Sterols in plants are considered to be structural components of cell membranes and they play a role in membrane permeability and serve as membrane stabilizers (Heftman, 1971). The ratio of sterols to phospholipids decreased with cold hardiness. Decreases in phospholipid content, degree of unsaturation in phospholipid fatty acids, and membrane fluidity were observed in the plasma membrane of the bark of mulberry trees during cold deacclimation. The sterol to phospholipid ratio increased with decreasing cold hardiness (Yoshida, 1986). However, the degree of unsaturation in the lipids of bark of black locust 'trees does not change during the year. Hardening of the bark cells during winter is correlated with increased total phospholipid levels (Siminovitch et al., 1975). Despite numerous investigations carried out on this subject, there is little information about changes in membrane lipids and their quantitative relationships during the growing season of decid- 